\title{
Reflections of "Culture Wars" on US Public Policy since World War II (Economic and Social Policy: Case Study $)^{1}$
}

\author{
Mohammed al Mogdad \\ Wisdom House Institute \\ Al al-Bayt University \\ Jordan-al-Mafraq
}

\begin{abstract}
The study aims to discuss the effect of "culture wars" on the reality and future of public policy in the United States from the end of World War II until the present time, as economic and social sectors were affected by the forces of political currents that dominate the American political system as a result of employing "populist" political programs Political and legislative positions have both conservative and liberal currents, which is reflected in the positive performance outputs that have led to results that are not broadly consistent with the needs of individuals and institutions in the state, especially among minorities, where poverty and poverty prevail. The level and quality of education, as well as the decline in the size of the middle class. On the other hand, foreign policy was also influenced by the theories of capitalism and liberal ideologies that prevailed globally as a result of theories called "postmodernism" such as Criticism, Feminism, Realism, Neoliberalism, and others. The study was based on the main hypothesis that "there is a correlation between the effect of "culture wars" between the various political currents in the United States and its reflection on public policy outputs." Based on the study problem, its questions, and its objectives, the study used each of the Historical, Functional, and Systems Analysis Approaches. The study concluded that there are many results, the most important of which is that there is a negative relationship between government roles and executive and legislative administrations and the extent of the ability to achieve better levels of efficiency and public policy outputs in the United States, as a result of ideological conflicts between conservative political forces on one side, and liberal forces on the other side.
\end{abstract}

Key Words: Culture Wars, Public Policy, Economic, Populism, Conservatives, Liberals, Postmodernism.

\section{Theoretical Framework of the Study:}

\section{I-1 Study Problem:}

American society consists of many subcultures that influence the nature of the ideological trends that underpin the data on political, intellectual currents in the United States, including those that are based on conservative ideological pillars and others that have liberal pillars in the currents that support openness and intellectual liberation based on freedoms and the rights of individuals.

The political and social forces have endeavoured to achieve a kind of serving the public interests, through societal mobilization that is based on winning the support of individuals and groups in addition to those forces, as this approach is called populism. This was reflected in the American public policy outputs since World War II, especially in the sixties of the last century until now. American politics have also been affected by the merits of capitalism and globalization, and by many theories in international politics, such as theories that are called postmodernism, such as feminist theory, criticism, realism, neoliberalism, and others.

The "culture wars" has become a vocabulary that must be studied when studying the American political system, due to ideological, political, and economic considerations, all of which have affected the concept of social stability in the United States. That is why this study comes to discuss this topic from the various aspects mentioned above, and through answering the following main question: How does "a culture of wars" affect US public policy outputs in general and social policy sectors in particular?

\section{I-2 Study Importance:}

The importance of the study lies in discussing and analysing the impact of the "culture wars" that characterizes the American "open society", and the extent of the influence of political and social forces on the American public in their populist programs to reach legislative or executive decision-making positions. Where historically these ideologies, whether liberal or conservative, still affect the reality and future of American society and public policy outputs.

\section{I-3 Study Objectives:}

\footnotetext{
${ }^{1}$ The research was accomplished during a sabbatical leave granted by Al al-Bayt University / Jordan 2019-2020, and cooperation with the Liberty University, VA, USA.
} 
There are many goals that the study seeks to discuss, and then to reach results related to the problem of the study, its importance and its questions, the most prominent of which are the following:

1- Discussing the political, intellectual ideologies that political currents believe in, represented by conservative thought on one side and liberal thought, on the other hand, through populist politics and an open society.

2- Knowing the impact of "culture wars" on the outputs of US public policy.

3- Knowing the theoretical concepts that appeared in the stage of what is called postmodernism, and that affected the shape of the American decision, especially in the field of public policy.

4- Discussing the relationship and influence of "culture wars" with religion, state components, and societal stability in the United States.

5- Reaching a general evaluation of the reality and future of what is termed "culture wars" and "open society" and the extent of its impact on US policy, and in other words, its impact on American society.

\section{I-4 Study Hypotheses:}

Based on the problem of the study, the questions and the goals mentioned above, the study is based on a significant hypothesis, which is: "There is a correlation between the effect of a culture of wars between the different political currents in the United States and the reflection of that on public policy outputs." From this main hypothesis, several sub-hypotheses are represented as follows:

1- There is a correlation between the influence of political and religious ideological ideologies, pressure groups, and consequently "populist" rhetoric, and the effect of this on levels of social justice in various fields in the United States.

2- There is a correlation as a result of the conflict between conservative and liberal ideologies on the one hand, and achieving intellectual balances that meet the aspirations of the various racial, ethnic, and minority groups that make up American society.

3- There is a correlation between the influence of American political decision-makers on the global ideology, and the extent to which ideological theories influence them called postmodernism.

\section{I-5 Study variables:}

Independent Variable: The Impact of " Culture wars" in the United States

Intermediate variable: political ideologies

Dependent variable: public policy

\section{I-6 Study limitations:}

The study deals with its topics during the historical periods that followed the Second World War until the beginning of the current century, in order to know the extent of the impact of intellectual and populist conflict on American policy. The study also discusses the most prominent international ideological theories, which are called postmodern theories.

\section{I-7 Study Methodology:}

The study will use each of; Historical, Functional, and Analysis System Approaches.

The Historical Approach will be used when tracing the "culture of wars" experienced by liberal and conservative ideas from the period after the Second World War until the beginning of the current century.

The Functional Approach will be used when dealing with the methods used by both those who believe in conservative politics and those who believe in liberalism as starting points in their programs and populist agendas, in order to mobilize the American public for their intellectual and electoral programs. The Analysis Systems Approach also used when discussing the policies that depend on it in the development process, which are related to government sectors and that are directly related to the public policy of the United States.

\section{I-8 Concepts of the Study:}

\section{Culture Wars:}

It is the cultural struggle between social groups and the struggle to control their values, beliefs and practices. It usually refers to hot button topics in which there is a general social difference and polarization in societal values. This term appeared to be commonly used to describe contemporary politics in the United States while describing issues such as abortion, multiculturalism, and other cultural struggles based on values, ethics, and lifestyle as the main political divide. (Hartman, 2015.33) 
In American usage, the term "culture wars" may imply a conflict between those values considered traditionalist or conservative and those considered progressive or liberal (Spahn,1910.9). It originated in the 1920s when urban and rural American values came into clear conflict. This followed several decades of immigration to the States by people who earlier European immigrants considered "alien". It was also a result of the cultural shifts and modernizing trends of the Roaring 20s, culminating in the presidential campaign of Al Smith in 1928. However, James Davison Hunter's 1991 book Culture Wars: The Struggle to Define America redefined the "culture war" in the United States of America. Hunter traces the concept to the 1960s (Holt, 2010.7). The perceived focus of the American culture war and its definition have taken various forms since then. James Davison Hunter, a sociologist at the University of Virginia, introduced the expression again in his 1991 publication, Culture Wars: The Struggle to Define America. Hunter described what he saw as a dramatic realignment and polarization that had transformed American politics and culture. $\mathrm{He}$ argued that on an increasing number of "hot-button" defining issues-abortion, gun politics, separation of church and state, privacy, recreational drug use, homosexuality, censorship - there existed two definable polarities.

Furthermore, not only were there several divisive issues, but society had divided along mainly the same lines on these issues, to constitute two warring groups, defined primarily not by nominal religion, ethnicity, social class, or even political affiliation, but rather by ideological world-views. Hunter characterized this polarity as stemming from opposite impulses, toward what he referred to as Progressivism and as Orthodoxy. Others have adopted the dichotomy with varying labels. For example, Bill O'Reilly, a conservative political commentator and former host of the Fox News talk show The O'Reilly Factor, emphasizes differences between "Secular-Progressives" and "Traditionalists" in his 2006 book Culture Warrior (O'Reilly, 2006.17).

\section{Postmodern:}

It is a broad movement that developed in the mid to late twentieth century through philosophy, art, architecture and criticism, representing a departure from modernity. This term has been applied more broadly to describe a historical era that is said to follow postmodernity and trends of this age. While encompassing a wide range of approaches and disciplines, postmodernity is generally defined by a position of doubt, ridicule or rejection of dominant narratives and ideologies of modernity, which often What calls into question the various assumptions of Enlightenment rationality. Consequently, the common goals of postmodern criticism include the universal notions of objective reality, ethics, truth, human nature, mind, science, language and social progress. Postmodern thinkers often draw attention to the potential or socially adaptive nature of epistemic claims and value systems and place them as products of particular hierarchical political, historical, or cultural discourse. Consequently, postmodernist thought is broadly characterized by tendencies to subjective reference, cognitive and moral relativity, pluralism, and dignity.

Postmodern critical approaches gained purchase in the 1980s and 1990s, and have been adopted in a variety of academic and theoretical disciplines, including cultural studies, philosophy of science, economics, linguistics, architecture, feminist theory, and literary criticism, as well as art movements in fields such as literature, contemporary art, and music. Postmodernism is often associated with schools of thought such as deconstruction, post-structuralism, and institutional critique, as well as philosophers such as Jean-François Lyotard, Jacques Derrida, and Fredric Jameson. Criticisms of postmodernism are intellectually diverse and include assertions that postmodernism promotes obscurantism, is meaningless, and that it adds nothing to analytical or empirical knowledge.

\section{Public policy:}

Public policy is a set of decisions made by governments and other political actors to influence, change, or frame a problem or issue that has been recognized as being in the political realm by policymakers and the wider public. Public policies include laws, rules, regulations, provisions, case studies, government programs, etc. Now public policies and their nature have become of three types - restrictive, regulatory and facilitating policies. (Anderson, 2000.27)

The procedural concept of public policy will be used when discussing "culture wars" and their impact on economic sectors and political and social stability in general.

\section{Liberalism}

Is a political and moral philosophy based on liberty, consent of the governed and equality before the law? Liberalism in the United States is generally characterized by a mixture of progressive and social liberalism, with a straight line. Less frequently, he may also describe classic and neoliberal forms. Liberals in the United States advocate stable and progressive civil liberties under which societal practices must be changed whenever necessary for the common good of society or the benefits of those who wish to engage in these social arrangements. They believe that government action is required for people to be as free as possible. Therefore, the government must guarantee the provision of positive rights, protect civil liberties and ensure equality. American liberals generally reject both biased and socialist capitalism as a means of distributing economic resources. A mixed economy, a capitalist free-market economy with limited government regulation and intervention, is seen as exemplary. Lately, there has been a strong movement 
among liberals against corporate welfare, which is generally favored by pro-government conservatives. Multiculturalism is very common among American liberals. ( Krauthammer, 2013.58)

\section{Conservatism}

Conservatism is a political philosophy that values traditions and established practices on social progress and new ideas, and this does not mean that they are purely reactionary. Conservatives have traditionally dealt with the spirit of the founding fathers: limited government, non-interference in foreign affairs, the free market, and strong personal freedoms.

In other words, Neoconservatism is a political movement born in the United States during the 1960s among the liberal hawks that became disenchanted with the increasing pacifist foreign policy of the Democratic Party, and the growing New Left and counterculture, in particular the Vietnam protests. Some also began to question their liberal beliefs regarding domestic policies such as the Great Society. Neoconservatives typically advocate the promotion of democracy and interventionism in international affairs, including peace through strength (through military force). They are known for espousing disdain for communism and political radicalism. ( Dagger, 2016.13)

\section{New Conservatives}

They represent a branch of conservative thought that has emerged during the Cold War and since the emergence of communism. This intellectual and practical movement is overgrowing in its power. As many conservatives have long started questioning non-interference in wisdom in other countries, it is an already weak school of thought due to World War II. Their conservative "new" brand placed a heavyweight on the strength of the military, the interaction of industry and government, and strong investment in industry and science. As a result, many of the principles of Paleoconservatism (the oldest conservative) were overlooked; government spending increased dramatically, personal freedoms eased with security concerns, and many wars and coups began with the goal of increasing American power, despite the persistence of intense moralism. ( Woods, 2004.47)

Consequently, we can know the difference between the conservatives and the neo-conservatives in America regarding public policy in a concise way as follows: The conservatives represent the conservative intellectual trend in the United States, and they have a political ideology that values free enterprise, small government, and strong international foreign policy. A sub current of the wallet. Their interest is usually focused on influencing foreign policy trends, and they are generally more willing to interfere in foreign conflicts in some capacities. Moreover, as these conservatives believe, the world and the United States are in a better position when the United States remains a global superpower. However, both conservatives and neo-conservatives have different ideas in an open, liberal thought that believes in near-absolute freedoms.

\section{Liberal Conservatism}

Is a political ideology combining conservative policies with liberal stances, especially on economic, social and ethical issues, or a brand of political conservatism strongly influenced by liberalism?

As for the procedural concept of both liberals and conservatives, it will be examined in the study - alongside concepts related to interest groups - when reviewing the intellectual conflict between political currents, parties, and social influences (pressure groups) such as religious authority, nongovernmental institutions, and others. Given the importance of clarifying this, it is necessary to refer to the following:

Political ideologies in the United States refer to various ideologies and ideological demography in the United States. US citizens generally classify themselves as committed to attitudes along the political spectrum, liberal, progressive, moderate, or conservative. Modern American liberalism aims to preserve and expand human, social and civil rights, as well as to ensure the government provides positive rights. It combines social progressiveness and liberalism to some extent and closely resembles European social liberalism. American conservatism commonly refers to a mixture of economic liberalism, liberalism, and social conservatism. It aims to protect the concepts of small government and individual freedom while promoting traditional values in some social issues. (Kristol, 2011.63)

In the United States, the size of ideological groups varies slightly, according to the survey. The Gallup USA Today poll in June 2010 revealed that $42 \%$ of respondents were conservative, $35 \%$ moderate and $20 \%$ liberal. In another poll, conducted in June 2010, 40\% of American voters consider themselves conservative, $36 \%$ moderate and $22 \%$ liberal, and described the strong majority of liberals and conservatives as being closer to the centre than the extremists. As of 2013, self-identified conservatives reached 38\%, moderates 34\% and liberals 23\%. (Saad, 2011.5)

The Pew Research Center, in a 2005 study, had identified nine taxonomic groups for intellectual, political, economic, and religious ideologies, all of which are currents that influence the repercussions of social life in the United States. Three groups were identified as part of each of them, "Left", "Political Center" and "Right". 
In this classification system, the right represents roughly the Republican base, the one on the left the Democratic Base, and the one in the independent centre. On the left are secular and mostly anti-war "liberals", conservative and economically conservative Democrats and "conservative Democrats" and economically "disenfranchised" Democrats who favor expanded government assistance. In the middle there are "optimists", optimists, moving up, the "disaffected", frustrated and unreliable, and disenfranchised "spectators". This right is comprised of highly pro-business "businesses", highly religious "social conservatives" (also known as the Christian Right) and "pro-government conservatives" who mostly protect social issues, but support government intervention to improve their lives. (Ibid, 2011.41)

\section{I-9 Previous Studies:}

Many valuable studies dealt with the subject of the study from multiple aspects, both those related to American and populist culture and those that discuss the ideological struggle between conservative and liberal political and social currents, in addition to the extent to which American culture and politics are affected by globalization and the political, economic, social and security ideological theories that appeared in a period Postmodernism. It is worth noting that this previous literature, including what is published in specialized books and periodicals, is evaluated according to scientific principles. In light of this, it is necessary to refer to a number of them in order to know their importance from one side, and how different this study is from those of previous studies.

In his book, "Culture Wars and Enduring American Delms."Author Thomson, Irene discussed Many topics related to the culture of wars in the United States, through different periods and periods, including each of Culture wars and warring about culture, respect for religion, but uncertainty about its role, moral, but not moralistic, American Individualism: Complexities and Controversies, pluralism within one culture, and culture, class, and American exceptionalism.

The author concluded many of the main results, the most important of which are: Cultural wars through images - from the "established radicals" in the academy, from "secular secularists" and "Christian fundamentalists", from the influence of "modernity" or "postmodernism" and the defeat of "traditionalism". Awareness of the role of these symbols causes groups of interests and scholars alike to try to separate "reality" from images. However, the reality of even such concepts as the American exception remains a matter of dispute. Is the United States exceptional because of its voluntary individuality and volunteerism or because of its continuing commitment to traditional ethics? Does this extraordinary lie in a minimum of class consciousness or a higher-than-usual devotion to religion? (Thomson,2010.218)

In another study, in their book called "Is There a Culture War? : A Dialogue on Values and American Public Life" the authors (Hunter and Wolfe) they make it clear that in the wake of many bitter presidential campaigns and the face of many contentious policy questions, many Americans question whether their country has split into two. People enthusiastically choose aspects of contentious issues such as the invasion of Iraq, gay marriage, stem cell research, and the right to die, and the battle for abortion continues unabated. The social and political divisions dazzle the media: we hear about the red states against the blue states and the "religious right" against secular America. "Fox News and Air America: NASCAR parents and football mothers. Is America, in fact, clearly divided? Is the moderate center still is there? Is the national fabric fading? To the extent that these divisions exist, are they simply unavoidable health products for a diverse democratic nation? Is there cultural warfare? Two of the leading American authorities in political culture are leading a deliberate and deliberate investigation of this issue and its implications. (Hunter, Wolfe. 2007.16)

James Hunter discusses and because Wolfe these questions are vital, with insight and in-depth knowledge rooted in the years of study and reflection. Long before most scholars and thinkers tackled this issue, Hunter and Wolfe were defining fault lines in the debate. Hunter's 1992 book " Culture Wars" put this term in popular circulation, Arguing that America was in the midst of a "culture Wars" the most basic and dear assumptions about how our lives were arranged., Wolfe challenged the notion of a "cultural wars". It argued that the majority of Americans were seeking compromise, a mixture of traditional and modern. For the first time, these two distinguished worlds join the dialogue to clarify their differences, update their arguments, and search for the truth about the American cultural situation. (Ibid,2007.17)

In his book "Religion, economics, and public policy ironies, tragedies, and absurdities of the contemporary culture wars" the author Walsh said; The ecumenism of orthodoxy consists of conservative Evangelicals, Catholics, Mainline Protestants, and Jews who "order themselves, live by, and build upon the substance of a shared commitment to transcendent truths and the moral traditions that uphold them." At the same time, secular Americans and "nominal religionists" do not.1 Concerning the political economy, the orthodox are said to lean toward laissez-faire capitalism while those who have drifted away from traditional religion lean toward liberal or Marxist views on political economy.2In one respect, I have found this conceptualization of the American religious landscape to be very useful. 
Analyzing the arguments of religious leaders who have reduced politics into war by other means, I find numerous illustrations of five fallacies of wartime logic. First, cultural warriors, who refuse to allow empirical evidence stand in the way of ideology, assume that if Left is right, further to the left is better, or if Right is good, further to the right is better. Second, the combatants present false dichotomies: either you are for us, or you are against us. Between "us" and "them," they see no alternatives. Third, culture wars foster the conclusion that "the enemy of my enemy must be my friend."Fourth, cultural warriors believe that humiliating the enemy is a necessary prerequisite for a lasting peace; thus, they insist that there be no negotiations, no compromises and no facesaving manoeuvres. Fifth, cultural warriors conclude that if our side cannot win the war, we must poison the wells so that nobody wins. In the process of divorcing ends from means, they often become what they hate. These five fallacies provide deeper insights into key ironies, tragedies, and absurdities of religion and American politics. (Walsh, 2000.x)

Also, the author reached several significant conclusions on the topics he discussed and explained the world religions have been functional and dysfunctional, liberating and oppressive, true and false. World religions have survived, in part, because each contains a multitude of symbol systems capable of numerous interpretations. People whose views are shaped by a world religion must choose (or have chosen for them) which stories, doctrines, or paradigms will shape their understanding of a particular issue. Consider the following: (Ibid, 2000.94)

- Comfortable Hindus might appeal to the principles of karma, reincarnation, and moksha (enlightenment) as a justification for the status quo or as a source of ethical obligation.

- Oppressed people might appeal to the notion of God's Justice is a call to arms or as a source of hope.

- Comfortable Muslims might appeal to the concept of God's providence as a justification for the status quo or as a reminder of God's judgment.

- Jews might appeal to the notion of a covenantal relationship with God as a justification for ignoring the suffering of non-Jews or as an inspiration to honour the image of God in all people.

- Buddhists might point to the illusory nature of material wealth to conclude that the redistribution of nothing is nothing, or they might appeal to the illusory nature of material wealth to affirm that human dignity is far more valuable than video games and toaster ovens.

- Christians must choose which narratives (and which interpretations of those narratives) are going to shape their ethical obligations. When discussing a specific economic policy, it matters whether they emphasize the story about the tower of Babel or the story of the rich young ruler, the story of the man who misused his talents or the story of the prodigal,

Jesus' statement that there will always be poor people or his statement that whatever you do to the least of your brothers and sisters, you also do to him.

In his article (Muste) entitled "Reframing Polarization: Social Groups and "Culture Wars" the researcher explained its recent analysis of American politics often call for the term "culture wars" that depicts sharp and growing divisions within the American political system. Most of this research defines culture in terms of values and beliefs about social issues. It identifies polarization in terms of partisan divisions and issues. I evaluate the claim of exacerbation of "cultural wars" using the concept of political culture focusing on social groups and measuring polarization as attitudes of members of a social group towards their social groups and in their external groups, and the effects of group attitudes on partisanship. An analysis of attitudes between groups from 1964 to 2012 of the social divisions determined by race, class, age, gender, and religion shows that the polarization of attitudes toward social groups is minimal and generally stable and that most members of a group feel positively toward external groups. The partisan and judicial polarization that appears in the previous research does not extend to deep or increased hostility between groups that can reinforce issues-based and partisan polarization (Muste,2014.01).

The researcher added that; a recent analysis of American politics often invoke the term "culture wars" depicting sharp and increasing divisions within the American polity. Most of this research defines culture in terms of values and beliefs about social issues. It defines polarization in terms of partisan and issue divisions. I evaluate the claim of worsening "culture wars" by using a conceptualization of political culture that focuses on social groups and measuring polarization as both social group members' attitudes toward their social-groups and out-groups, and the effects of group attitudes on partisanship. Analysing inter-group attitudes from 1964 to 2012 for social group cleavages defined by race, class, age, sex, and religion shows that polarization in attitudes toward social groups is minimal and generally stable. Most group members feel positively toward out-groups. Partisan and issue polarization seen in prior research does not extend to deep or increasing inter-group hostility that could reinforce issue-based and partisan polarization (Ibid, 2014.02). 
Finally, and despite the importance of the previous studies and others who discussed the subject of the study, this study comes to discuss the effect of a "culture wars" on the outputs of US public policy, based on the goals and questions of the study that was addressed in the theoretical framework for this study.

\section{II. "Culture Wars" in the History of American Society}

A follower of political currents in the United States notes that there are many changes in a conservative culture, especially during the past fifty years, which are considered a "culture wars" between the various political parties to reach the presidential or legislative authority as the liberal social demands led to the introduction of culture "Populism" in the service of balances between liberal demands and strict demands, and in all areas of public policy, such as social policy, economic policy, justice, civil rights, social security, etc., as well as in the field of foreign policy towards Cooperation or conflict in the humanitarian, economic and military fields. Moreover, these reflections are called (open society).

The intellectual and political struggle that served the concept of liberal liberalism adhere to the approach of " open society" and the constant push to change some conservative laws, thus did not serve the concept of "political containment"( Hunter, 2006.37) through "social containment"( Glover, 1996.16). Where, paradoxically, the thought of many groups that support an "open society" has become opposed to some social concepts and phenomena that offend morals, and that they are not completely satisfied with the transformations that are taking place in American society, where feminists and civil rights activists and communists have sought to impose their moral values through Promote the regulation or abolition of speech or behavior that they believe is offensive, insensitive, or intolerant towards women or people of other races or cultures. (Cochran,2015.421)

These political features call us to analyse and evaluate the paths of transformations in the component of the political and social system, on the one hand. The opinion of the conservative religious current represented by Christian thought in America through the presentation of ideological views and the rules of the Bible, on the other hand.

The concept of the "open society", which provides for tolerance and diversity of all political, social, and religious points of view, is a philosophy that the US Supreme Court has appeared increasingly more willing to side with when interpreting the constitutional rights of individuals. However, this idea of the open society sometimes runs counter to the moral values of groups on both the Left and the Right of the political spectrum. As these groups attempt to enact their moral values as public policy, their plans can sometimes conflict with individuals' constitutional rights. (Ibid.417)

The 1960s brought about tremendous social change in the United States. The United States Supreme Court was in the middle of this change.

During this time, the court became more involved in preserving the ideals of individual freedom, especially in the area of the rights of suspected perpetrators, the right to privacy, and freedom of expression. Even before the 1960s, the court was moving toward greater participation in protecting individual freedoms and moving away from disputes over the new deal of government regulation of the economy. The court's move to protect these individual rights sparked a backlash among conservatives (both conservative Republicans and conservative Southern Democrats). In a speech in 1969, President Richard Nixon appealed to the "silent majority" in the hope of uniting conservatives. Against the permissiveness of the more liberal counterculture of the 1960s. (Ibid.417)

The intellectual and political scene in the United States has witnessed some important shifts on many issues related to moral values. For example, during the 1980s (Reagan's reign) the "blue republican movement" emerged that reflected a deeply rooted populist tradition in American history and shifted the issue of focusing the American right from a prominent interest in protecting the self-organizing market and the interests of the commercial and capitalist classes in society to a prominent interest in social issues and protecting their view of public morals (Ibid.418). Where this movement, which is considered from the American conservative right, supported the interaction and commitment to the capitalist market economies that support the idea of a free market and openness to the global economy. In other words, taking all the data of the capitalist economic system that focuses on the ideas of "Adam Smith" in freedom of ownership, free market, freedom of investment - activating the private sector, limited role of the public sector, and thus employing Smith's rule "let him work let him pass" (Fisher, economic policy).

The call to preserve the path of an "open society" in America did not stop at social mobilization and political discourse, but through activism and practical behavior by all political and social perspectives, as the important test of this was at the beginning of the twenty-first century due to the perceived threat to Extensive scope for radical Islam by committing terror in the United States. There have been calls to silence radical mullahs who claim to preach to their young followers in their schools (Muslim Today Schools) the duty to launch violent attacks on Americans (Ibid.422). Here, the value of an open society lies in tension with the need to provide security that prevents the indiscriminate killing of civilians, which led to the Patriot Act issued after the events of September 11, 2001.

\section{I the Main of Political Ideologies and Factors that Influence the US Political Arena}




\section{1-The Nationalities Factor:}

The Nationalities Factor in the United States of America is affected by the social structure, as the homogeneity of society is directly related to social and security stability, and in contrast that the heterogeneity in society negatively affects the attitudes of individuals, groups, and government. It also leads to not adhering to a unified vision and orientations in the political system. With these laws, it becomes difficult to implement (Friedman.2007, 76).

The evaluation of the national factor as a result of the global policies that emerged after the end of the Cold War has declined in many regions and countries. Where, due to wars on the one hand, and support for freedom of ethnic and racial minorities, on the other hand, has led to a retreat in the concept of state sovereignty and the preservation of the nation's national identity and national identity. As minorities demand independence from the state under the justifications of the right to self-determination, this led to instability of states and areas of international influence. For the United States, this may lead to intellectual and cultural divisions and a decline in the level of cohesion of American society and the level of security stability (Ibid.87).

\section{2- The Cultural Factor:}

This factor is related to the ideological factor referred to previously. The role and influence of the cultural factor in American politics are clear, when American society is more similar in its culture that is based on moral and religious values, with the right to maintain respect for diverse cultures provided that they maintain the course of the nation's state and respect the constitution and laws that All of them respect the concepts of equality, freedom and justice (Lal, 1999, 77-79).

\section{3- The Historical Factor:}

The historical factor means "all the different effects that the historical experiences, values, and social traditions of American society have on the various effects on the behavior of individuals and institutions of members of society and the state, as well as the relationship of the government." The historical factor contributes to the interpretation of the past to advance the present and the future of the state. For this, positive experiences remain an essential determinant of the political authority in directing the decision and then the best behavior, which in turn reduces the risks, negatives and difficulties of the decision, and reaching results that are consistent with the interests and goals of the desired state. (Ghosh, 2006, 109)

\section{4- Values and Trends Factors:}

The concept of values includes all symbols that members of society adhere to, such as respect for freedom, the other opinion, equality, responsibility, and the preservation of public interests and state institutions (Caprara, 2006.22). Where the US Constitution focused on respecting the inherited religious values. However, the values are not considered an essential or significant indicator of society or government that believes in secularism and conformity with the requirements of modernity, which was focused on post-modern political theories. This is what (Fischer, Presntation2) referred to, as he explained that the recent theories that influenced American policy in recent decades, such as the critical theory and the theory of cultural pluralism, the theory of equality, the theory of Westernization, etc., all of these theories affected political and social life in the United States of America. Where these modern theories and the so-called post-modernism have moved away from the parameters of sound cooperation based on love, justice and respect for humanity. Instead, it was devoted to increasing human killing as a result of wars, and paying attention to economic indicators based on international competition that led to the destruction and undermining, and without attributing this to Christian religious values, which the founding fathers who were greatly influenced by the universal Christian concepts, which they wanted to be a reference Of medieval Christian ideology based on traditional liberalism. Moreover, that the US government policies from its disadvantages are that they were later influenced by the ideas that derailed the American policy from its required course as a result of emotional and spiritual influence (Ibid, p29). That is why the contemporary and postmodern theories that have emerged since the 1970s must be evaluated so that the orientations of American politics and society are based on several foundations: Relationship with God, truth, values, awareness of the meaning of life, relationship with the other, and thus the inclusion of these elements or factors in Determine trends in US policy toward the relationship with the world.

Political values cannot lead to direct political action. They will be reflected in all components and goals of the state and in a positive way, except if it is continuously and consistently adopted by the government at the level of public policy internally, on the one hand, and by the decision-maker and decision-maker on the international political scene, on the other hand, because this leads to a real and credible image based on local and foreign credibility with all international political units. Because the values practised by the government or the executive branch expresses the sum of collective values that express the social factor among individuals, society and the American state (Ibid, 33).

\section{II The Impact of Ideological Trends in the United States in Public Policy}


Since the end of World War II, and during the four decades that followed, many government policies have been affected by the intellectual movements that prevailed in the United States by the American community, especially the economic and social sectors, on the one hand. The state administration was also affected by the ideological theories whose ideas spread on the scene Global politics, on the other hand. These changes also led the executive departments to practice American governments to work to confront the challenges facing American society, especially those related to ethnic minorities, in order to confront social and class distinctions between individuals and institutions of American society. Accordingly, this study will clarify several aspects, as mentioned by several specialists in this aspect who have provided essential ideas in this field.

The social rights movement in the United States of America, which grew clearly between the years (1950-1980), was influenced by liberal concepts demanding details of civil and economic rights. Likewise, with the global political ideologies that have influenced decision-making among American presidents and governments, since the administration of (Franklin Roosevelt) and beyond. Marxist ideas, modernism and post-modernism theories, that all are directly affected both the fundamental rules of the Bible and the Conservative-Liberal ideas that founded the American state that the founding fathers were keen on, which are considered a basic pillar in the face of "secularism" in separating religion from the state.

In the social sphere, the liberal ideas dominated the youth and women's groups, especially among blacks, and a leader (Luther King) who advocated non-racial discrimination, equal rights and duties with all members of American society. It thus led to a protest revolution that was considered a "generous revolution", which led to a definite interest by the government in finding solutions through reform policies, which led to low rates of "ethnic inequality" in the areas of poverty, unemployment, wages, health insurance, education, housing, and others. As well as in giving job opportunities to black women and youth to eliminate class deficiency and interest in preserving middle classes. As this led to a very large doubling, (where rates of increase in most areas of government support reached twenty times) in the cost of social assistance provided by the US government, especially between the years 1960-1987 (Murray, 1984.14).

(Murray) made it clear that the size of unemployment increased during the fifties, especially among black youth and women, knowing that the problem of unemployment and inflation is not new in the features of American society and economy. However, there was a problem that appeared during the mid-sixties related to the behavior of work and experience, related to the spread of a phenomenon Poverty among the black youth category, where the labor department worked in developing unique programs for job development that cost $(8 \mathrm{~g})$ billion dollars. In the 1970s, the balance of payments for work programs and confronting unemployment rose to (76.7) billion dollars. Federal government spending during the period (1965-1980) is approximately equal to that of Balance of Payments of the Labor Department (Ibid. 69-70).

The government training programs that prepared and supported them financially contributed to facing the causes of poverty and unemployment, especially among the minority of blacks in America, reaching (6.1\%) in 1979, compared to $(2.9 \%)$ at the end of the sixties of the last century. (Murray, P. 63). Economic prosperity in the form of technocratic idealism was the goal and legitimate purpose of the individual and American society in general. Many young people rejected this subordination to the democratic technocratic ideal because they considered it an influence on the reality of their social life. However, most cultural critics believe that men and women built the technocracy without any significant plan and worked for a common goal only because they agreed on common assumptions about what constituted Success, some imagined that technocracy was an imposed social order (Shires, 2007.112). American policy has been influenced by modern ideology, especially in adopting the liberal, egalitarian, and Marxist communist theory, among others, which has increased interest in training and education that leads to the disappearance of racial differences in employment rates, and leads to the occupation of leadership positions based on the introduction of the so-called "popular wisdom" (Murray, 1984.124). This is based on post-modern theories in the face of social and economic problems (Fischer, 2020). Although there was a counterculture to the emergence of the Evangelical movement in the late 1970s and early 1980s that represented religious thought from neo-conservatives, they had a radical activity on American institutions - be it religious, economic, social, or political. (Shires, 2007.44)

Referring to the tables related to unemployment, poverty, inflation and wages, we notice that many variables have positively affected the impact of American society, especially among black young men, males, and age. Moreover, they were at better rates and percentages in the nineties compared to previous periods (1950-1980). The reason for this is government policies that helped to increase job opportunities, adjust wage rates and distribute jobs equitably, which contributed to low ethnic differences in the American labor market. Taking into consideration that this had negative aspects on the economy of the United States, especially on the balance of expenditures or payments in the American budget, even though the cost of the payments was not positive, as the US government pays large amounts of money to young people. They were in their twenties and before, especially in The primary, secondary and university education stages, where black students became equal with whites and others in entering schools during the eighties, and colleges for those between the ages of (20-24) in 1990, and by (23.7\%) compared to (17.7\%) in 1980, 
where The volume of related government support (social support) To (664) billion dollars in 1990, compared to an average of (226) billion dollars in the seventies of the last century (Murray,1984.146-148).

The major problem still facing American society is related to the culture of poverty and the problem of birth rates outside the marriage for blacks. As the culture of poverty in the lower class carries the same values as the middle classes, where poverty rates did not change in the eighties compared to the period of the sixties and seventies. Birth rates outside marriage were in 1980 the percentage (55.2\%) compared to $(65.2 \%)$ in 1990 Compared to the white color $(11 \%)$ and $(20.1 \%)$, respectively, for the mentioned years, (Murray, 1984. 140-142), as well as see tables No. $7,18,18$, due to the influence of modern ideologies and non-conservative thought, and distance from values Religious and moral, and the absence of self-censorship due to the failure of the absolute sovereignty of Go by this broad segment Of American society.

Based on the outputs of US government policies and related to public policy since the end of World War II until the nineties of the last century, we can reach the following points:

1- There are statistical differences in the rates of the size of poverty, unemployment, education and social security among Americans according to race, among blacks compared to whites. It was found that the differences between all social variables such as age, male and female, educational levels.

2- There are statistically significant differences related to income differences for blacks compared to other American society, which prompted increased government support from federalism and at the state government levels.

3- The American state has worked at its various levels of implementation (federal, state, and local) to provide training programs to reduce the percentage of the executive and administrative leadership gaps in the various departments of the state.

4- The American administrations have been affected since the era of President Franklin D. Roosevelt until now in the ideological ideas that prevailed in the global community, which are called modernism and post-modernism theories as a result of the so-called "globalization" such as new Marxist theory, Critical, Feminism, Multiculturalism, and Queer theory, all of which contributed to Adopting the concepts of secularism (separating religion from the state), and with this, the conservative-liberal concepts that the founding fathers wanted and the concepts of morals and religious values have become isolated and gradually from the reality of government policy and large size of American society, and this It also contradicts "the concept of the absolute sovereignty of God and the absence of self-censorship" (Ibid,2020), for example, the percentage of births outside marriage in the United States is still increasing for blacks and whites together, (Murray,1984.141)

5- Despite the civil rights movement that contributed to confronting racism - and promoting public freedoms and equality, and that the American administrations contributed to, especially after the sixties and seventies since the last century, they did not reach the concept of justice.

To clarify this more broadly, the research study in the next section will address both the concepts of modern and post-modern theories that prevailed in the cosmic or global arena and how they affected American policy and how it differs with religious concepts and conservative principles in the United States.

\section{I Theoretical Concepts of Modernism and Postmodernism Theories}

Many ideological theories have emerged since the founding of America. All of them rejected any spiritual ideas, considered that religion is merely and that it does not work for progress and growth, and considered that man can develop through science and technology and natural motives for success from his human nature. (Fischer: Lecture 3).

Among the most prominent Marxist and progressive theories. Where Marxism emerged intending to change society due to the outputs of the industrial revolution, and the result of the industrial revolution was exploitation, monopoly of resources, and control of the means of production by those with capital. Where people are moving from the areas in the city to work in factories, and they work long hours in addition to child labor. That is why (Marx) found that these conditions lead to a societal explosion because it is not possible to own productive institutions, capital and open market, which all serve the "capitalism" that led to humiliation for people, because of control over the means of production. Hence, Marx presented the solution by highlighting the concept New which is "Communism". Which is summed up by the principle "of each according to his ability, and according to his needs." (Anievas, 2010.44)

In the sense that it focused (Marxism) on the concept of work and the distribution of resources. Both political leaders, who believed in "Marxist" thought, used both political and military power to serve the concept of communism, such as Lenin and Stalin. The results subsequently led to the killing and dominated by the Communist Party, which controlled the government, society, and the state. (Adams, 2007.53) 
As for the Critical Theory, whose concepts evolved with the twentieth century, leads to the imagination that life develops as a result of several levels of decision, so the focus must be on government and bureaucracy, and allow experts to control and authority. In short, the monetary theory is no different from Marxism, as they all considered the cause of underdevelopment to be due to exploitation and corporate greed. Moreover, the economical solution to this is through the strength of the government and the state presidency in setting legislative rules governing the interactions of the economic process. Thus, the ideas of each of them are described as secularism, as it has been deprived of presenting spiritual and ideological values (Fisher, 2020).

Also, the Theory of Multiculturalism focuses on the vocabulary of "Culture" stemming from customs and traditions that enable a group to face control over the exploitation of others, without clarifying the extent of the relevance of that culture to the spiritual concepts contained in the Bible. (Ibid, 2020.2).

Feminist Theory has also emerged, which is based on how to confront the rule and control of men and demand their right to be free from exploitation and to protect them from the oppression of society. (Fisher, Presentation2).

From the Queer Theory, the intellectual outputs of all modern and postmodern theories can be summarized as saying that the government should be concerned with managing the distribution of resources and facing control and exploitation of the individual and the group.

It focused on the concept of family values to protect the family, respect for equality and not just focus on the economy as it is in postmodern theories. (Ibid, 2020.2)

\section{II The Impact of "Culture Wars" on American Public Policy: Religion and the State}

\section{1) "Culture Wars" and Religion Issue in the United States:}

The relationship between religion and the state in the United States was not recent, and religious denominations usually focused on the intellectual and educational aspects dealt with by the Bible. Moreover, to confront scientific concepts and social problems.

Protestant modernity was not Christian at all because it got rid of supernatural theory and traditional doctrines such as atonement and bodily resurrection. Although fundamentalists focused primarily on theological battles within their denominations, many of them became interested in the significant cultural changes affecting American society during the early twentieth century. The issue with the most significant political implications was the teaching of Charles Darwin's theory of biological evolution in public schools. In contrast, other conservatives during the first half of the twentieth century continued to avoid religious arguments for their positions explicitly.

For example, when a group of southern farmers responded to negative caricatures of the South in the aftermath of the Scopes experimental catastrophe, there was only one article ("Allen Tate's Notes" entitled "Notes on Southern Religion" in "I will take my position" 1930 Devoted to religion (Smith, 1997.105). While they appreciated the critique of modernity implicit in fundamentalism, most farmers did not adopt a certain form of Christianity, and their attack on the industry was not based on theological grounds (Smith, 2016.204). As it became a familiar path, these conservatives appreciated the social benefit of religious obligations. However, they were reluctant to adopt them personally.

Likewise, the Post-WWII confrontation with atheistic communism prompted some conservatives to reassert religious arguments clearly; however, conservatives once again made a mostly utilitarian argument for the social role of popular religious belief, rather than building a comprehensive Christian political theory. During the fifties of the last century, Dwight Eisenhower (1890-1969) expressed the utilitarian approach of Americans towards religion and politics, saying: "The form of our government makes no sense unless it is established in a strongly perceived religious belief, and I do not care what it is Eisenhower, "the Soviet hostility to the free government - and religious faith," which he considered the basis of it (Smith, 2016.205).

American administrations were affected by religious pressure groups, and in all political speeches, presidential and legislative election campaigns, and local administrations were keen to use religious concepts (Ellis, 2007.75). And the use of common denominators between the Christian and Jewish sects. The religious structure also influenced American foreign policy. Where the United States supports Israel, given the impact of AIPAC in many political, security and economic aspects. After the $9 / 11$ events in 2001, Christianity had the most significant opportunity to influence American foreign policy compared to before, and Conservative Christianity became involved in consultations with the White House and Congress (Marsden, 2013.258).

Religion also contributed to guiding public policy in America, both in religious institutions that support poverty, social welfare and health care and in creating charitable and voluntary civil society institutions and everything that promotes social security. 
By analysing the reality of the challenges facing social and economic policy in the United States and the methods of solving them, we find that government reform policies are still substandard. Although the reform process resulted in a huge cost of effort by the executive branch and the Congress. Various American administrations have made efforts to meet the needs of the individual and develop resources, administrative and economic institutions in order to achieve social excitement.

American society has experienced many crises, including those related to the problem of racial discrimination, which contributed to the increase in poverty and unemployment, the low level of education, and the rise in crime rates. Because of the weak social justice, especially before the Second World War, which necessitated a review of the system of legislative laws, which led to the issuance of the Civil Rights Law in 1964, which emphasized the rules of equality and confronting racial discrimination, and the lack of disparity between members of society regardless of color, race or Religion, career status, or level of education.

The United States lived and is still living in an intellectual struggle and a state of the discussion by many decision-makers and social influence centres as long as they led to divisions between the major parties in the United States until they led to what is called a " culture wars" in order to modernize and develop through legislative reform and political action. However, these liberal or conservative ideas did not reach the required balance between the needs of individuals and society and the goals of the state. As many policies failed, the old policies in dealing with social and economic problems became better than the current policies. For this, they will remain interested in public policy in the United States about the justice and humanity of the alternatives. (Murray, 198). However, on the other hand, can one live independently of others? Is it justice that God wanted "as long as the earth and what God has to do" for the rich to live without the poor helping? If the government is responsible for solving community problems, then what are the requirements for solving problems within the concept of social justice? Is liberal ideology or capitalist economics the ideal model for solving social and economic problems? If so, why then do we see the problems increase, or is the problem in the application of Adam Smith's theory which called for a free economic approach, an open market and respect for private property, and within his famous saying, "Let him do it, let him pass"? (Fischer, 2020). However, with the controversy and concessions that the "conservative war" between the conservative right and the liberal left engendered as a result of "populism (Cochran, 402), then solutions must be found that reduce the size of social, economic and political problems, and choose the best alternatives that serve all components of the American state, whether the government Or individuals and public and private institutions (Murray, 1984,196).

Socio-political movements have led to changes in thinking toward the political right and the left. This is the result of a struggle in "populism", which has led to tolerance on social issues such as moral issues and civil rights. Where the populist methodology has led to a shift in anti-religious faith to the logical wisdom of the masses to hostility in thought, like the big companies that try to benefit from it, in this regard, populism also sees the interests of these ordinary people as opposed to the conspiratorial elites such as bankers, big corporations, bureaucrats, and politicians. Likewise, such as unskilled workers, small shopkeepers, small farmers and others whose modernization forces seem to have played out their roles well-being (Cochran, 415,418).

As a result of these "populist" influences, changes occurred in religious and political alliances, with evangelical Protestants, fundamentalists, and traditional Catholics joining mainstream Protestants such as Catholics, bishops, and ageing as the primary support for the Republican Party. Thus, it can be said, the popular revolution on the American right was largely a rebellion against secularism and increased social tolerance for Americans culture. In particular, the evangelical and fundamentalist clientele of the new populism was offended by the extent to which this secularization became a goal of official policy. (Ibid, 2015.419)

The real reality generated by the so-called "culture wars" and "populist" policies by political and economic power centers and those who aspire to decision-making positions needs to review and evaluate the general effects that have affected the reality and the future of the United States. The theory of "social justice" calls for sincere work, which is based on spiritual values "faith and religion", humanity and responsibility for work for the benefit of both the state and society, which is related in its entirety to the concept of "social work" provided that the goal of the work is not to achieve self or narrow interests.

To clarify the concept of "social work" and its relevance in "culture wars", we recall here what (Stoesz) mentioned, who accused decisively that the future is "grim" for liberals unless they become "more diverse in their policy repertoire", and the same can be said for conservatives and moderates. Stoesz is right that the social work profession must include critical, multi-dimensional thinking that has its roots in justice theory if it has a fundamental role in the policymaking process. Social workers, including teachers, should take advantage of the power of social media while enjoying the data collected by national and international organizations (Colby, 2013.16). If the social work profession continues to rely on political, philosophical, or ideological beliefs, the vast and existing social and economic contradictions will become more entrenched. A fair policy is achievable by mixing practical wisdom with objective thinking and criticism guides the theory of justice, which provides for the promotion of the interests of the less fortunate. 
Many social issues have emerged in the United States that the religious right has opposed, and have led to conflict within the Republican Party and intellectual and political divisions. There are elements of the Republican Party who focus on traditional Christian morals, where the religious right has expressed its opposition to policies that grant the right to abortion and gay and lesbian rights, including the 2003 US Supreme Court ruling in Lawrence v. Texas, which provides protection based on privacy rights for adults who consent to same-sex relationships, as well as 2013 Supreme Court decisions that allow same-sex marriage $\mathrm{N}$ in California and the recognition of same-sex relationships for sexual access to federal benefits. On the other hand, libertarian populists were on the rise in the Republican Party, which created a struggle within the party, at times, between the goals of social conservatives and liberals.

Unlike social conservatives, libertarians are not concerned with private morals at all but instead focus on enacting policies that create a smaller government with fewer taxes and fewer rules and besides social issues. (Ibid, 2015.420)

There was also a conflict between the American presidents regarding economic and social issues, which confirm once more the "culture of war" between the Republican presidents and the Democratic presidents who express their decisions about the opinions of the parties they represent during their presidential administration of the White House. For example, since the early 1970s, social and economic reforms have stopped abruptly, and conservative militancy has become increasingly victorious. There was a "southern strategy" for Republican Nixon with its withdrawal from strict implementation of civil rights, Democrat Jimmy Carter's attacks against transportation industry regulations, Republican Ronald Reagan's declarations that "the government is not the solution, and the government is the problem," and the deregulation of Republican George Bush Sr. From the industry Energy, Democrat Bill Clinton's embrace of the deep cuts in luxury, the elimination of bank restrictions, and harsh prison terms for petty crimes. After Republican George W. Bush's efforts to cut taxes on the wealthy, and in the face of more and more powerful conservative opposition, Barack Obama's claim of "yes we can" (Murray.150,152). And the restriction of President Trump's immigration policies and policy toward national security and the Middle East peace process. These are all examples of how "a culture of war" affects American public policy, as it reflects the instability of public policies, which in turn reflects on the American citizen.

Within the concept of "culture wars" there are many examples that confirm the changes and transformations in traditional conservative currents in America and led to tensions between conservatives and liberals in the Republican Party, which appeared decades ago as a result of the so-called "populism", especially in electoral races. For example, many social conservatives supported the former Pennsylvania Senator Rick Santorum, who was a mainstay of his campaign, both opposing abortion and gay marriage and focusing on tough military policy such as Bush's foreign policy. On the other hand, the libertarian Ron Paul, who - despite his nominal opposition to abortion - was not focused on this issue at all. Paul also voted to change military policy by allowing homosexuals to serve publicly and advocated the legalization of marijuana. Instead, the focus of Paul's campaign was to dramatically reduce government spending and reject the Bush-era policies that called for military intervention in promoting democracy. Moreover, Republican Party candidate Mitt Romney nominated Ryan for vice president, because Ryan was strongly opposed to abortion but also supported some liberal views. (Ibid, 2015.420)

In foreign policy, both politicians - on the old right and liberals - tend to emphasize tolerance, universality, and openness to other cultures, and the belief that most international issues can be resolved through diplomacy, which in turn has led to the emergence of a new right that is more "chauvinistic" and oriented toward potential opponents. (Ibid, 2015.420).

\section{2) “Culture Wars" and Social Stability Issue in the United States:}

The public policies that were used previously - before and after the sixties of the last century - can be reviewed, and then evaluate those previous experiences, because among these experiences there are many positive aspects of evaluating the process of social reform. Because practical procedures in the application may be responsible for the negative consequences of undesirable outputs when designing theoretical strategies. Also, the review of these stages may have internal and external influences that have affected the course of the reform plans in the matter of social welfare. This means that the United States was affected by the stages of applying capitalism and economic openness, and facing communism and socialism during the Cold War, as well as by postmodern theories, neoliberalism, feminism, economic globalization, global ideological, cultural, technological competition, camp support, western alliance, and military proliferation Direct and indirect intervention - these many challenges - have roles affecting public policy, finance, and social welfare.

Historically, such external and internal factors have imposed themselves on society and government together, and as we get essential results when reviewing previous experiences, and lead us to correct the paths of mistakes that were caused by "populism", "culture of war" and "open society" and the race to political centers, administrative, or legislative, pressure groups, interest groups, liberal, ideological, and economic groups. Generally, it can be said, the emerging importance of social issues in American society lies in the presence of tension with another emerging force in American politics. 
The concept of "open society" requires tolerance of diversity in all social, political and religious perspectives, i.e. recognizing that the various provisions on these issues They all have the right to protest and defend them, and to legitimize a warring society intellectually, racially, ideologically, diverse and between a hard-line conservative who believes in the constitution and the ideas inherited from the founding fathers who believed in conservative-liberal thought, and between a free liberal thought that believed in Total openness in various social and economic aspects and not restricting the individual's liberties and instinctive whims.

Thus the concept of an open society means that in matters of social, political or moral judgments, no one has a monopoly on truth or wisdom (Cochran,2015.421). Therefore, it makes sense to leave the communication channels open, and an among all the bodies that affect society and state power through the government as the executive and the Congress as the legislative and all political, economic and social movements.

The reality of parties and political participation in the United States is a significant obstacle to providing new solutions or ways to produce better results in public policy, because the dominant parties since the independence of America remained dominant and have a similar internal structure, bearing in mind that some considered it a form of institutional democratic stability for the parties, so no president from outside the Democratic or Republican parties came, as well as the two parties remained in control of both sides of the Congress, whether the House of Representatives or the Senate, as well It applies to state governors and local councils. This fact, when the voter has political participation makes him in front of a traditional authority compared to models from democratic and capitalist countries such as Britain, France, or Germany in which political action centers change between a time period and another.

Also, a long time ago, the structure of the major parties in America was a significant concern in theory and practice. James Price sees in the federal form or what he called the American Commonwealth "that the major parties are organized in America, considering that they have the distinctive feature of politics in the United States on the one hand, and we considered it a kind of positive conflict on the other hand. On the other hand, Henry Jones saw Ford in a book" The Rise and Growth of American Politics "The parties themselves were instead a boon to salvation, the only characteristic of politics in America that saved them from an impractical constitution and continued political frustration (Shafer, 2019.122).

On the issue of discrimination and women's rights, social movements have recently emerged against racial discrimination and support for women's rights. Given the importance of these movements, we will review the following two movements and their impact on American society and their interaction with "social justice", and ideological political competition, and the future of these movements. "Black Lives Matter" was started by community organizers Alicia Garza, Patrice Khan Colors and Opal Tomeite in response to the acquittal of George Zimmerman in 2013, the shooting of an African American teenager, Trivon Martin, a chapter-based and member-led project. The task is to build local power and intervene when violence occurs in black societies (Hooker, 2016.449). The "Me Too Movement" was also founded in 2006 by social activist and community organizer Tarana Burke as part of a popular campaign to promote "empowerment through empathy" among women who have been sexually abused, especially young women from low-wealth societies. In October 2017, actress Alyssa Milano encouraged the use of the "hash tag Me Too" on social media to help reveal the prevalence of sexual assault and harassment, especially in the workplace. After millions of people started using the hashtag, the conversation entered the national dialogue. The movement has now grown to include men and women of all colors and ages. In addition to empathy, there is also a focus on identifying the best ways to hold perpetrators accountable and stop the cycle.

Such of these movements and events can help to devise solutions and applications, foster hard work toward engaging in an active resistance policy that does not fit easily into the boundaries of liberal democracy, that may be absolutely crucial to the achievement of ethnic justice. Blacks are political heroes (Hooker,2016461). Taking the idea of riots seriously as a form of democratic reform for black citizens means recognizing that the responsibility for "racial justice" does not lie primarily with those who have already suffered the losses caused by racism, but rather by monitoring the consequences of wrong behavior and deterring those who violate judicial rulings And applied according to the identities of the state and society together.

There is much to be commended about the resurgence of these two movements, at least at present, from a society that continues to suffer from discrimination towards minorities to a clear extent, and from a society in which women did not feel empowered to report harassment - either because of fear of infidelity or fear of belief but being ignored for a person with many women, he now feels that both of them and their faith may be heard by those who have the power to make the change (Edgar,2018.125). Therefore, from the standpoint of both "social justice", developing the necessary methods to confront discrimination against blacks and abuse of women, and this requires the "judicial system" in the United States, developing and applying a doctrinal framework that rejects misconceptions about objectivity and facilitates the use of a specific objective standard that examines each case according to standard equity, fairness, and equality for people in society. However, there is continued support for women's reasonable standards in the harassment law; the standard must also be rooted. 
Moreover, the solution to which we must always remember, the solution to social problems such as racial discrimination against black minorities and women is associated with faith and good morals that begin with the values and behavior of people, and this is reflected in all society, the state and all governmental and civil institutions, and this confirms that "absolute power" is for God. Only not the government, the people, or the church (Fisher,2020) because human rights are among the rights of God, because the land is for God and what is on it.

\section{A general Evaluation of the Impact of "Culture Wars" on the Reality and Future of Public Policy in the United States.}

At all levels of policy, the complexities of the support phenomenon must be taken into account when planning support and research interventions. Projects must involve more than just collecting data; to better know whether social support benefits people and how that is, we need to conduct practical research as interventions are field-tested with theory. These interventions should be aware that at least two people participate in social support exchanges. For the interventions to be effective, the "cost of care" must be taken into account. All people involved in the support process should be considered and minimize negative impacts (Brownell, 1985.118).

When using a multi-period model, we need a species analysis problem and comparing the expected impact of additional support with other intervention options. First of all, the problems for which interventions are recommended can be categorized under three rules: (1) problems that represent personal problems (such as "culture wars" and populism, social justice, discrimination, immigration), the effects of which are amenable to support interventions; (2) Problems that represent social issues (such as economic policies, air, or polluted water), the effects of which are unlikely to be controlled by support interventions; and (3) problems that represent social problems (such as social and health care, education), which are likely Its effects are amenable to support the interventions(Brownell,1985.111). By making such distinctions, we can define appropriate intervention policies. Accordingly, the study will focus on several aspects of these various topics.

The phenomenon of "culture wars" and "open society" policy, supported by liberal social and economic ideas, led to changes in the values of the American family and society. Where the family's role in preserving its children has become recognized due to social movements that support the liberation of people from all restrictions, and have relied on the concept of equal rights, and it is among the inalienable rights. For example, the movement for equal rights and equal treatment for gays and lesbians is a natural extension of the open society. However, this movement offends the goals of some groups that promote family values. For example, gays and lesbians have asked (successfully) that they are allowed to serve in the armed forces without regard to their sexual orientation. They have also pursued the right to be treated equally in marriage — working for the legal recognition of same-sex marriage (Ibid, 2015.424).

Healthcare policy in the United States, despite the high cost of the fiscal policy and the annual budget of the balance of payments, is not easy to undo, except through positive alternatives or incentive incentives that contribute to reducing the cost to the government on the one hand and the beneficiary of health care from another side. Murray, here he presented good models in dealing with the cost of smoking for the smoker and the government, which are reflected in the income of the individual and the state (Murray, 207). Also, dealing with the human right to health is subject to two interrelated perspectives: The right to medical care, which requires access to high-quality medical services. It includes the four primary measures to assess the compliance of healthcare systems with the human right to health No. 14 of the United Nations Committee on Economic, Social and Cultural Rights (2000): availability, accessibility, acceptance and quality. The right to health, which depends on favorable social, economic and political conditions. It includes three types of state obligations: respect, protection and fulfilment (Parker, 2019.24). As with all spending problems, there are two basic ways to address them: 1 . Increase the revenue to pay the ever-increasing healthcare costs by making third-party payers, and those with insurance pay more for insurance premiums and having people with insurance pay higher deductibles and copayments 2 . Reduce the costs of the services of cutting the price paid for healthcare services. Consuming fewer healthcare services. (Vonderembse, 2017.23).

A solution depends on understanding and applying the principles of patient-centred care (PCC) and resource management. Also, the implementation is difficult because there are many participants in the healthcare delivery value chain, such as physicians, nurses, and medical technicians, as well as many provider organizations, such as hospitals, clinics, physician offices, and labs. Further up the value chain, there are pharmaceutical companies, equipment providers, and other suppliers. These participants have diverse and sometimes conflicting goals. However, each must be willing to accept change and work in a coordinated manner to improve healthcare. To overcome these problems, strong national leadership is needed to get the attention and support from the people and organizations involved in healthcare and to make the comprehensive changes that will lower healthcare costs, improve healthcare quality, eliminate delays, increase access, and enhance patient satisfaction. (Vonderembse, 2017.26).

Once again, the proper path of what we have learned from the overlapping of public and social policies is to stop at the reasons for establishing these policies and the reasons for their success or failure on the one hand and how they can guide those policies in scientific and social methods. 
On the topic of social welfare, where the history of prosperity in America represents the public opinion and reflects firm values and beliefs. As a policy, well-being today is usually seen as the TANF cash assistance program, which evolved from the 1935 Social Aid (ADC) provisions of the Social Security Act. However, TANF is a very small part of the welfare programs and services provided by the government (Colby, 2013.117). Federal and state and local government efforts to provide social welfare are much greater than TANF. In the context of our entire social welfare, government participation in programs such as Social Security and Medicare outperforms contributions to TANF. On the other hand, the years 1935 to 1996, and more than 15 years since the last experiment of social welfare reform, reveal a journey in societal policies and programs that affect changing values and beliefs and call for a new kinder and kinder approach, a way that affects social sympathy. (Colby, 2013.125)

In light of this, it is necessary to review the social welfare programs periodically in terms of the extent of the entitlement of those who are included and the extent of the necessary support, because many people who receive care in a period may not deserve it in subsequent periods because of changing his conditions for the better. That person may not be entitled to a full cost of costs Care, and this applies to healthcare, education, poverty and others.

The issue of the future of immigration in the United States, aside from immigration reform itself, developing a National Action Alliance can benefit immigrants and the labor movement. Unions can become nationally susceptible to the political mobilization and social transformation of Hispanic immigrants and others today, echoing the dynamism that arose in California after 1994. Organized work, with its vast financial resources and administrative capacity, alongside advocacy organizations for Latinos and Latinos, is now preparing to take over this The agent role. Moreover, most importantly for the massive wave of working-class immigrants from southern and eastern Europe, when a wave of unions in the 1930s and 1940s and the accompanying political integration helped narrow the disparities between the haves and the have-nots and pay many migrants of the generation the first and second in the middle class - and in the Democratic Party. History may not repeat itself, but sometimes it is rhymed (Voss, 2011.185).

In the issue of legal justice, the judiciary in the United States was influenced by a "Culture Wars" and "an open society" long before the Second World War, political and ideological battles in the Supreme Court mostly dealt with the amount of power that the federal government had (And state governments) in regulating the economy. These battles culminated in clashes between the court and President Franklin D. Roosevelt during the Great Depression of the 1930s. However, then over the past few decades, the battlefield for political battles over moral values in courts often ends, as the Supreme Court and US constitutional law often rule the standards of public policy options available to a government when it seeks to implement social policy on ethical values issues that Strongly discussed. In other words, in battles of moral values, the United States Supreme Court has increasingly interpreted the constitution in favor of the concept of an open society (Cochran, 2015.225). Also, the court has always adopted the constitution as a basic reference in the results of its legal rulings. Despite the influence of political and social movements that support the so-called "freedom to speak", the Supreme Court has weakened this principle over the years and allowed a wide range of intolerance rhetoric on the basis that these words are protected under the constitution. In the Chaplinsky case, the Supreme Court upheld the conviction of Chaplinsky, one of Jehovah's Witnesses, because, in his essence, he was screaming at a police officer, describing him as a "cursed fascist" and a "cursed Racketeer of God." Who was tried by Chaplinsky is prohibited by "any law that is offensive, ridiculous or disturbing to anyone else on the street legally "(Ibid, 2015.439).

The future of defending an "open society" and "culture wars" will remain in the coming decades from the political and societal aspects in the United States. Capitalism and social liberalism and freedoms due to the tendency to achieve economic interests and political and administrative centers. Also, the Constitutional Court will remain in front of many societal issues that demand freedom from traditions, in other words. In general, the Supreme Court has adopted over the past half-century in many cases, an explanation of the constitution that supports the view of the open society (Ibid, 2015.466). The efforts of the Conservatives mostly (but in some cases, the liberals as well) to impose their moral visions on the rest of the country were not particularly successful. Moreover, when analysing most of the actions of the Supreme Court, we can conclude that the goal of the concept of civil liberties is that there are some things that the majority cannot do for the minority, regardless of how strong that majority is and regardless of how severe it is, and that there is no solution to the issues that ethics or religion may be considered permanent. Accordingly, it can be said that such issues will continue in the struggle between all political and social forces during the current century.

As policies become ever more densely packed and commingled together, it is increasingly difficult to demonstrate success to the American public. The era of big programs with big results - like Social Security or Medicare - are long gone. Moreover, when big programs like prescription drug benefits for Medicare seniors are enacted, they are so difficult to understand and deliver that the voices of approval are drowned in a sea of discontent. Today, both policy entrepreneurs and policymakers must work very hard to demonstrate that they make a difference in the lives of the American public. 
That is why mastery of the process and control over the agenda has become so important to policy advocates and policymakers alike. At least this enables them to deliver many minefields to a broad array of niche constituencies (Biggs, 2007.379).

The process of reforming the American social policy requires the introduction of the so-called "positive incentives" towards reducing the financial cost in order to cooperate and energize the needy individuals and groups in the various sectors that the government bears social health care, and that many of those interested in the process of social welfare reform in the United States addressed, Such as (Murray), which is considered one of the convincing and useful theoretical and practical approaches when developing future plans by decision-makers and those who are relevant in this field. There is nothing morally reprehensible in restrictive methods of using only "positive incentives".In theory, positive incentives are guaranteed to have very low success rates, as they depend on a technique that significantly changes human behavior, and on the use of negative reinforcement with positive reinforcement of the targeted people. The more deeply rooted the behavior that must be changed and the more attractions. It is reserved for the person who participates in his behavior.

Most importantly, the programs concerned in the incentive process must contain a complete set of tools available on the one hand, and the participant's willingness to follow up with all that is required in employing social programs to deal with unemployed militants, mothers Delinquent teenagers, addicts, etc., on the other hand. In practical terms, when temptations get big - as they should, if the program deals with the most intractable problems - the more attractive it becomes to people who do not need help (Murray, 1984.223). However, we must take into account that the application of positive incentives in social programs in a democratic society tends to cause net harm in dealing with the most challenging problems because the target groups of social welfare will naturally tend to have enough motivation to produce bad behavior. It is not a solution to stimulating good behavior; the more difficult the problem, the more likely this relationship will prevail (Ibid, 2017.218).

The main theme of the American public policy reform process related to poverty and racism is that for a long time, the consequences were catastrophic for the poor of all races as a result of policies and social, ideological outlooks. It affected the black poor in particular, and most importantly for poor blacks in entire black societies - And it is precisely that group that has been the target of great sympathy. To deal with the racial issue of social welfare is to repeal every part of the legislation, and to reverse every decision of the court in any way requiring, recommending, or granting preferential treatment, according to race. Thus, this brings us back on the path left in 1965 . This may lead to a debate over the appropriate limits of government intervention in trying to impose the ideal. However, at least it should be possible to define the ideal: race is not an ethically acceptable reason to treat someone differently from the other (Ibid, 1984.217).

Social problems today are complex matters that affect all people, regardless of age, race, gender, race, or marital status. These problems create great barriers to creating just societies. Although the issues seem overwhelming, social concerns in one form or another will always be part of our landscape and thus ideological. This is not intended to be a pessimistic remark, but it reflects the unique aspects of the human condition (Colby, 2013.15). We need to look at the role of religion in the American state, what are the issues that we find solutions in the Bible, and how can we employ them in theoretical and practical solutions to the problems facing the United States?

Finally, regarding US foreign policy and its impact on the reality of federal and local public policy, the United States will face an increasingly difficult international environment in the first quarter of the twenty-first century. The agenda will likely be dominated by transnational issues such as the environment, energy and water, as well as the impact of a significant global population increase. Capitalism, globalization and all postmodern liberal and political theories will aggravate the gap between the poor and the rich. The United States will need to adjust its foreign spending and develop new tools to deal with these new security threats, in order for US governments as a front to be able to counter rising public debt, cut costs, and pursue an economic and public policy through which they provide social care in all its aspects. ( Cameron, 2005.195)

\section{Conclusion:}

In light of what has been presented in the content of the study, and based on the objectives of the study, its questions and the hypothesis on which it was based, the research study concluded many facts and results, the most prominent of which are the following: -

- There is a clear impact from "culture wars" on the various practical behaviors that the executive and legislative authorities have applied for decades to various sectors of public policy in the United States of America.

- Political ideology in the United States is characterized by the ideology of both political and conservative currents and liberal democracy. 
- American policy has been influenced by "populist" trends that influence the programmatic approach of candidates to reach decision-making positions in both governmental and legislative authorities, whether at the level of local government in the states or at the level of the federal system.

- Conservative ideology in the United States is influenced by both religious doctrinal concepts and the foundations established by the founding fathers, and the preservation of the rules of the American constitution and thus conservative democratic foundations, compared to the liberal democratic movement, characterized by flexibility and freedom from conservative restrictions and traditions.

- The American administrations were influenced by the capitalist economic approach and the global ideological theories that emerged and are called "postmodernism", such as the liberal, realist, feminist, monetary, and other theories, which led to the interaction of foreign policy with international policy data in order to maintain centers of influence, market openness, and freedom of trade, including Consistent with the rules of the World Trade Organization and the privatization of companies and a significant reduction in the level of government oversight, and this all led to the absence of distribution justice and social justice as a result of the direction of profit with companies and without direct interference by the government, or positive reform And my work through the legal and legislative system.

- "Culture Wars" led to an increase in the balance of expenditures, especially in the health and education sector, and this led to a continuous increase in the federal budget deficit on the one hand and the budget of local governments.

- The study concludes in light of the analysis and results stated that the US government needs to rearrange its executive and legislative policies so that it is based on new strategies consistent with the needs of the American state so that it can reduce the risks of economic gaps and the absence of social justice in all sectors of the state and its governmental and non-governmental institutions.

- Finally, there is clearly a negative correlation between the performance of government authorities in the United States as a result of a "culture wars" and public policy outputs, especially in recent decades, which necessitates more cooperation between conservative and liberal political currents on the one hand, and the institutions of civil society on the other.

\section{Resources}

Adams, R. (2007). The Ends of America, the Ends of Postmodernism. Twentieth-Century Literature, 53(3), 248-272. Retrieved January 23, 2020, from www.jstor.org/stable/20479813

Anderson, James. (2000). Public Policymaking: An Introduction, 4th Ed. Boston: Houghton Mifflin.

Anievas, A. (Ed.). (2010). Marxism and world politics: Contesting global capitalism. Retrieved from https://ebookcentral-proquest-com.ezproxy.liberty.edu

Baum, M. A., \& Potter, P. B. K. (2015). War and democratic constraint: How the public influence foreign policy. Retrieved from https://ebookcentral-proquest-com.ezproxy.liberty.edu

Beyers, Jaco. (2014). The Effect of Religion on Poverty. HTS Theological Studies, 70(1), 01-10.

Biggs, S., \& Helms, L. (2007). The practice of American public policymaking. Armonk, N.Y: M.E. Sharpe.

Brownell, A., \& Shumaker, S. (1985). Where Do We Go from Here? The Policy Implications of Social

Support. Journal of Social Issues., 41(1), 111-121. https://doi.org/10.1111/j.1540-4560.1985.tb01119.x

Cameron, F. (2005). U.S. foreign policy after the cold war: Global Hegemon or reluctant sheriff?. Retrieved from https://ebookcentral-proquest-com.ezproxy.liberty.edu

Caprara, Gian Vittorio et al. (2006) "Personality and Politics: Values, Traits, and Political Choice." Political psychology. 27.1:1-28

Colby, I. C., Dumas, C. N., \& Sowers, K. M. (2013). Social work and social policy: Advancing the principles of economic and social justice. Retrieved from https://ebookcentral-proquest-com.ezproxy.liberty.edu

Caputo, R. K. (2011). U.S. social welfare reform: Policy transitions from 1981 to the present. New York, NY: Springer Science+Business Media, LLC.

Crossley, J. (2008). Jesus in an Age of Terror Scholarly Projects for a New American Century. London: Equinox Publishing Ltd.

Dagger, Richard. (2016). "Neoconservatism". Encyclopædia Britannica. Retrieved 16 May 2016.

Demarest, H. B., \& Borchard, E. D. (2018; 2019 ;). US national security reform: Reassessing the national security act of 1947 (1st Ed.). Milton: Routledge. DOI:10.4324/9781351171564

Drinan, R. F. (1963). Religion, the courts, and public policy (1st Ed.). New York: McGraw-Hill.

Demy, T., \& Stewart, G. (2000). Politics and public policy: a Christian response: crucial considerations for governing life. Grand Rapids, MI: Kregel Publications.

Fisher, Kahlib. (2020).Presentation: The Battle of Ideas in the Policy Arena. Liberty University, VA. USA.

Fisher, Kahib. (2020).Presentation: Worldview \& Political Ideology Activity 1 
Fisher, Kahlib. (2020). Presentation: Worldview \& Political Ideology Activity 2

Friedman, Sally. (2007). Dilemmas of Representation, Local Politics, National Factors, and the Home Styles of Modern U.S. Congress Members. Albany: State University of New York Press,

Edgar, A. N., \& Johnson, A. E. (2018). The struggle over black lives matters and all lives matter. Retrieved from https://ebookcentral-proquest-com.ezproxy.liberty.edu

Ellis, R. E., Coe, K., \& Domke, D. (2007). The god's strategy: How religion became a political weapon in America. Retrieved from https://ebookcentral-proquest-com.ezproxy.liberty.edu

Lal, Deepak. (1999). "Unintended Consequences the Impact of Factor Endowments, Culture, and Politics on Long-Run Economic Performance." Cambridge, Mass: MIT Press,

Ghosh, Peter. (2006) Goldman, Lawrence, and Matthew, H. C. G . Politics and Culture in Victorian Britain Essays in Memory of Colin Matthew. Oxford: Oxford University.

Glover, J. (1996). Humanity: A moral history of the twentieth century. Retrieved from https://ebookcentral-proquest-com.ezproxy.liberty.edu

Halper, S., \& Clarke, J. (2004). America alone: the neo-conservatives and the global order. Cambridge: Cambridge University Press.

Hanson, Paul D. (2015), Adams, Sharon, and Taylor, Allison. A Political History of the Bible in America. First edition. Louisville, Kentucky: Westminster John Knox Press,

Hartman, Andrew. (2015). A War for the Soul of America: A History of the Culture Wars.University of Chicago Press.

Holt, Douglas. Cameron, Douglas. (2010). Cultural Strategy. Oxford University Press.

Hooker, J. (2016). Black Lives Matter and the Paradoxes of U.S. Black Politics: From Democratic Sacrifice to Democratic Repair. Political Theory, 44(4), 448-469.https://doi.org/10.1177/0090591716640314

Hunter, J., \& Wolfe, A. (2006). Is There a Culture War? A Dialogue on Values and American Public Life. Washington, D.C.: Pew Research Center.

Krauthammer, Ch. (2013). "Democratic Realism," in Things that Matter. New York: Random House.

Kristol, K. (2011).“The Right Stuff,” in The Neoconservative Persuasion, New York: Basic Books.

O'Reilly, Bill. (2006). Culture Warrior. New York: Broadway Books.

Parker, R. (Ed.), García, J. (Ed.). (2019). Routledge Handbook on the Politics of Global Health. London: Routledge, https://doi-org.ezproxy.liberty.edu/10.4324/9781315297255

Rettig, R., \& Levinsky, N. (1991). Kidney failure and the federal government. Washington, D.C: National Academy Press.

Marsden, D. L. (2013). For god's sake: The Christian right and us foreign policy. Retrieved from https://ebookcentral-proquest-com.ezproxy.liberty.edu

Marshall, K., \& Van Saanen, M. (2007). Development and faith where mind, heart, and soul work together. Washington, DC: World Bank.

Murray, Charles. (1984).Losing Ground American Social Policy, American Social Policy, 1950-1980, basic book.

Muste, C. (2014). Reframing Polarization: Social Groups and "Culture Wars". PS: Political Science and Politics, 47 (2), 432-442. Retrieved May 10, 2020, from www.jstor.org/stable/43284567.

Saad, Lydia. (2011)."U.S. Political Ideology Stable With Conservatives Leading".Gallup, Inc.

Shafer, B., \& Wagner, R. (2019). The Long War over Party Structure: Democratic Representation and Policy Responsiveness in American Politics. Cambridge: Cambridge University Press. DOI: $10.1017 / 9781108753517$

Shires, Preston. (2007).Hippies of the Religious Right: From the Counterculture of Jerry Garcia to the Subculture of Jerry Farwell Kindle Edition, Baylor University Press,

Smith, F. J. (2016). Religion and politics in America: An encyclopedia of church and state in American life. Retrieved from https://ebookcentral-proquest-com.ezproxy.liberty.edu

Smith, O. (1997). Fundamental Differences: Baptist Republicans Political Partners. In The Rise of Baptist Republicanism (pp. 98-112). NYU Press. Retrieved March 2, 2020, from www.jstor.org/stable/j.ctt9qg8g4.10

Spahn, Martin (1910). The Catholic Encyclopedia. New York: Robert Appleton Company.

Thomson,I.T.(2010). Culture wars and enduring American dilemmas. Retrieved from https://ebookcentral-proquest-com.ezproxy.liberty.edu

Vonderembse, M., Dobrzykowski, D. (2017). A Healthcare Solution. Boca Raton: CRC Press, https://doi-org.ezproxy.liberty.edu/10.1201/9781315367767

Voss, K., \& Bloemraad, I. (Eds.). (2011). Rallying for immigrant rights: The fight for inclusion in 21st century America. Retrieved from https://ebookcentral-proquest-com.ezproxy.liberty.edu

Walsh, A. D. (2000). Religion, Economics, and Public Policy: Ironies, Tragedies, and Absurdities of the Contemporary Culture Wars. Greenwood Publishing Group.

Woods, T. (2004).A Politically Incorrect Guide to American History. Washington, D.C.: Regner. 